\title{
A Case of Affinity Among Tupí, Karíb, and Macro-Jê
}

\author{
Aryon D. Rodrigues ${ }^{2}$
}

\begin{abstract}
Based on morphosyntactic data from Tupían, Macro-Jê, and Karibean languages I shall present fundamental linguistic evidence favoring a hypothesis of genetic nexus between these three South-American native groups of languages, each one of which represented by languages whose location reflects the geographical diaspora of their speakers in pre-historical times. The hypothesis has benefited from previous work on the genetic relations between Tupí-Karíb (Rodrigues 1985), as well as between Kaingáng and Tupían (Rodrigues 1978, unpubl.). In this paper I also bring substantial foundation for a Macro-Jê stock (Rodrigues 1986). ${ }^{3}$

Keywords: Morphosyntax, genetic relationships, South American Indian languages, MacroJê-Tupí-Karíb.
\end{abstract}

\section{Resumo}

Com base em dados morfossintáticos de línguas Tupí, Macro-Jê e Karíb, apresento evidências linguísticas fundamentais para a hipótese de um nexo genético de três agrupamentos de línguas nativas sul-americanas, cada um deles representado por línguas cuja localização reflete a diáspora de seus falantes em tempos pré-históricos. A hipótese beneficiou-se de estudos anteriores sobre as relações genéticas entre Tupí e Karíb (Rodrigues 1985), assim como entre Kaingáng e Tupí (Rodrigues 1978, ms.). Neste estudo apresento também fundamentação substancial para o tronco Macro-Jê (Rodrigues 1986).

Palavras-chave: Morfossintaxe, relações genéticas, línguas indígenas sul-americanas, MacroJê-Tupí-Karíb.

\section{Introduction}

In this paper a case of grammatical congruence among Tupí, Karíb, and Macro-Jê languages is presented as a further evidence of the likelihood of a

\footnotetext{
${ }^{1}$ Research supported by Conselho Nacional de Desenvolvimento Científico e Tecnológico (CNPq).

${ }^{2}$ Professor Emérito do Departamento de Linguística, UnB, e Laboratório de Línguas Indígenas $\mathrm{LALI} / \mathrm{IL} / \mathrm{UnB}$.

${ }^{3}$ This paper was written by occasion of the 1992 meeting at the University of Colorado for Jeseph Greenberg. My Macro-Jê hypothesis has been further developed in Rodrigues (1999, 2000), as well as in Rodrigues and Cabral $(2005,2009)$.
} 
closer affinity among these three major linguistic groups of South America. This adds not only to my paper on Tupí-Karíb relationships (Rodrigues 1985), but also to the lexical and phonological correspondences between the Jê language Kaingáng and the Tupían Tupínambá and Tuparí that I presented in 1978 (Rodrigues 1978, unpubl.). I will first describe a morphosyntactic situation in the Tupí-Guaraní family, represented here by Tupínambá (2.1.). This family is a close-knit one and most of its languages behave like Tupínambá in the area of grammar dealt with here. The Tupí-Guaraní family is one of the branches of the Tupí linguistic stock (Rodrigues 1958a). Data from three other branches will be presented after Tupínambá: the Tuparí family, represented by the Tuparí language (2.2.); the Mundurukú family, represented by Mundurukú (2.3.); and the Mawé language, a one-member further branch of Tupí (2.4.). The presentation of these data is intended to show that at least four branches of Tupí share the same morphosyntactic pattern, so that this can be supposed to have been a feature of Proto-Tupí and may be used to compare this with other linguistic stocks. In section 3 . comparable data from the Karíb family will be presented. Such data reveal the same morphosyntactic pattern found in the Tupí languages. Karíb examples will be taken from three languages: Hixkaryána of the Guyana branch of the family (3.1.), Taulipáng of the North Amazonian branch (3.2.), and Arára of the South Amazonian branch (3.3.). In section 4, the corresponding situation in languages of the Macro-Jê stock will be discussed. In 4.1. languages of the Jê family are examined, namely Timbíra, specifically the Canela dialect (4.1.1.), Panará (Kren-akarore or Southern Kayapó) (4.1.2.), and Kaingáng (Paraná dialect) (4.1.3.). In section 4.2. Ofayé, a one-member branch of the Macro-Jê stock, will be shown to have the same morphosyntactic pattern. In section 4.3. it will be seen that Karajá, another member of Macro-Jê, presents also the same pattern, albeit only in a small set of lexical items. Section 4.4. will present a longer discussion of Kipeá, a language of the Karirí family, which is another branch of Macro-Jê (Rodrigues 1986). This discussion aims at showing that Kipeá (and Karirí), although strongly divergent in syntactic typology, has reflexes of the same pattern found in the languages examined in the previous sections. In section 4.5. Boróro (Eastern Boróro), a language of a further branch of Macro-Jê, the Boróro family, will be shown to be comparable in some relevant forms to Timbíra and to have these forms probably descended from the same morphosyntactic pattern discussed here. Finally, in section 5. it will be concluded that the grammatical pattern found 
in full form or only in vestiges in the languages considered here constitute one more indication of probable genetic relationship among Tupí, Karíb, and Macro-Jê, besides being of course a further evidence for the consistency of the Macro-Jê stock, five branches of which have been examined.

Besides the pattern dealt with in this paper, there are several other structural similarities among Tupí, Karíb, and Macro-Jê, which will not be treated here. Those listed below prevail in each of the three language groups, even though some languages may deviate in some details:

1. Typical vowel system: $i$ i u e a o $+\tilde{\imath} \tilde{z} \tilde{u} \tilde{e} \tilde{a} \tilde{o}$ (some languages have no nasal vowel phonemes and some have only one back vowel; the languages of the Jê family have nine oral vowels: $i \tilde{z} u$ e ə $o \varepsilon a$ c, and some of them have $\Lambda$ as a tenth oral vowel);

2. (Morphological) distinction between inclusive and exclusive 'we'.

3. Distinction between alienable and inalienable possession.

4. (Morphological) person markers precede the verb, mood/aspect/tense markers follow it.

5. Nouns, postpositions, descriptive words, and transitive verbs behave similarly in relation to their determiners: the genitive of nouns, the head of prepositional phrases, the subject of descriptive words, and the object of transitive verbs.

6. Adjectival words follow the noun, either as free words or as members of an attributive compound.

7. Relational words are typically postpositional.

8. (Only) nominalizations are used as relative clauses.

\section{Tupí}

\subsection{Tupínambá}

The Tupí-Guaraní languages are characterized, among other things, by a set of grammatical morphemes that have been called "relational prefixes". Two of these prefixes were opposed already by the first grammarians (Anchieta 1595 and Figueira 1621) of Tupínambá, a language spoken in the $16^{\text {th }}$ and $17^{\text {th }}$ centuries along the coast of Brazil, as marking the contiguity or non contiguity of a genitive before a noun, a subject before a descriptive verb and a subordinate intransitive one, a direct object before a transitive verb, and a noun before a postposition: 
(1a) wirá $r$-áßa (F 73)

bird REL-feather

'the feather of the bird'

(1b) s-áßa (F 73)

REL-feather

'its feather'

(2a) kwesé kaجá rupi owatáßo pedro r-opári (F 94)

yesterday woods through walking Pedro REL-go.astray

'yesterday, when he walked in the woods, Pedro went astray'

(2b) kwesé kaiá rupi pedro owatáßo s-opári (F 94)

yesterday woods through Pedro walking REL-go.astray

(Same meaning as in 2a)

(3a) maPékatú asé tupã r-awsúßa (F 74)

thing.good we God REL-love

'It is a good thing that we love God'

(3b) ma?ékatú tupã asé s-awsúßa (F 74)

thing.good God we REL-love

(Same meaning as in 3a)

(4a) emąẽ óka r-esé

look house REL-at

'look at the house!'

(4b) emarẽ s-esé

look REL-at

'look at it!'

In the examples above the prefix $r$ - occurs when a determining noun phrase immediately precedes a noun (1a), a descriptive verb (2a), a transitive verb (3a) and a postposition (4a), and the prefix $s$ - occurs when the determined item is not immediately preceded by the determining one because the latter was either omitted $(1 b, 4 b)$ or displaced to another position in the sentence $(2 b$, 
$3 b)$. For the sake of easy reference the prefix $r$ - may be labeled "contiguity marker" in contrast with the prefix $s$-, which may be called "non-contiguity marker". This description is a rather superficial one, but it will give us a sufficient basis for the comparisons we are going to make among Tupí, Karíb, and Macro-Jê languages.

In Tupínanbá, as in most Tupí-Guaraní languages, nominal, verbal, and postpositional stems are divided into two main lexical classes distinguished by the allomorphs of the markers of contiguity and non-contiguity. Let us call these classes A and B. Examples (1a)-(4b) above were taken from class A. The allomorphs for both classes are the following:

Contiguity Class A Class B

Non-contiguity

$\begin{array}{cc}r- & \varnothing- \\ s-, t- & i-\end{array}$

Examples of class B:

(5a) Pedro ø-pó (A 2v)

Pedro REL-hand

'Pedro's hand'

(5b) aikotúk i-pó (A 50v)

I.stab REL-hand

'I stab his hand'

(6a) kwesé pajé ma?éasíbóra Ø-subáni (F 95)

yesterday shaman sick-one REL-suck

'yesterday the shaman sucked the sick'

(6b) kwesé maPéasíbóra pajé i-subáni (F 95)

yesterday sick-one shaman REL-suck

(Same meaning as 6a)

All stems belonging to class A begin with a vowel, whereas most, but not all, stems in class B begin with a consonant.

The situation just described for Tupínambá is found in most languages of the Tupí-Guaraní family with only slight phonological differences in the 
prefixes (for instance, Tupínambá $s$ - is $t s$ - in Guarayo, $h$ - in Old Guaraní, and - in Wayampí).

\subsection{Tuparí}

Tuparí, spoken on the Rio Branco, an affluent of the Guaporé river, in Rondônia State, Brazil, is a member of the Tuparí linguistic family, another branch of the Tupí stock. Although differing from the Tupí-Guaraní languages in a good part of its lexicon as well as in many grammatical features, Tuparí presents the following set of prefixes for the contiguity/non-contiguity opposition:

Contiguity Class A

Class $\mathrm{B}_{1}$ Class $\mathrm{B}_{2}$ Non-contiguity $\begin{array}{ll}\boldsymbol{D}^{-} & h- \\ s^{-} & i_{-}\end{array}$ $\varnothing-$ $i-$

Class A includes only stems beginning with a vowel, class B1 consists also of stems beginning with a vowel, and class B2 has both stems beginning with a consonant and stems beginning with a vowel. Examples (data from Caspar and Rodrigues 1957):

(7a) роера ø-ера

moon REL-eye

'moon's eyes' (= 'Stars.')

(7b) $s$ - epa

REL-eye

'its eyes' (= 'Stars.')

(8a) toto h-aip

grandfather REL-son

'grandfather's son'

(8b) i-aip

REL-SOn

'his son' 
(9a) papit ø-ape

Pabit REL-path

'the path of Pabit (a kind of spirit)'

(9b) i-ape

REL-path

'their path'

(10a) aramira o-pe

woman REL-dress

'the dress of the woman'

(10b) i-pe

REL-dress

'her dress'

\subsection{Mundurukú}

Mundurukú, a language of the Mundurukú family, also a branch of the Tupí stock, spoken mainly on the upper Tapajós river in Pará State, Brazil, exhibits the same morphosyntactic pattern for the contiguity/non-contiguity distinction:

Contiguity

Non-contiguity

$$
\text { Class A Class B }
$$$$
d-, n-\quad \varnothing_{-}
$$$$
t-\quad i-, j-
$$

Class A includes only stems beginning with a vowel and class B, stems beginning with a consonant as well as with a vowel. In class A contiguity is marked by $d$ - before oral vowels and by $n$ - before nasal vowels. In class B non-contiguity is marked by $i$ - before consonants and by $j$ - before vowels. Examples (data from Crofts 1973):
(11a) tawe $d$-o
monkey REL-blood
'the blood of the monkey' 
(11b) t-oj pakpap

REL-blood red

'the blood is red' or 'its blood is red'

(12a) tawe $n$-ãj

monkey REL-tooth

'teeth of monkey'

(12b) sîko $t$-ãj

five REL-tooth

'five teeth'

(13a) tawe $i-k \tilde{o}$

monkey REL-tongue

'the tongue of the monkey'

(13b) i-kõ i-bi-be

REL-tongue REL-mouth in

'the tongue is in the mouth'

(14a) $\quad o-\int i \quad \varnothing-b i$

1-mother REL-mouth

'my mother's mouth'

(14b) $i-b i$

REL-mouth

'her mouth'

(15) j-å̃̃abida

REL-heart

'its heart'

According to Crofts (1973:84) $i$ - is the basic form of the obligatory prefixes of $3 \mathrm{rd}$ person, whereas stems which begin with $/ \mathrm{d} /$ or $/ \mathrm{n} /$ replace these phonemes by $/ \mathrm{t} /$ in the $3^{\text {rd }}$ person, without taking the prefix $i$-. For Crofts, therefore, $/ \mathrm{d} /$ and $/ \mathrm{n} /$ in such cases are not prefixes, but initial consonants of the stems, subject to a morphophonemic change to $/ \mathrm{t} /: i$ - ' $3{ }^{\text {rd }}$ person' $+d o j$ 
'blood' $\rightarrow$ toj 'its blood'. This analysis is justified synchronically, since $d o j$ and toj are the only existing forms of the Mundurukú word for 'blood' and

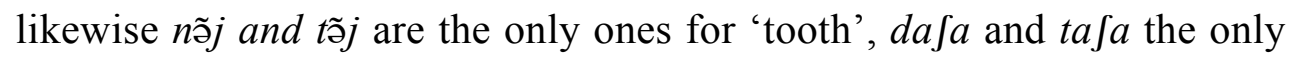
ones for 'firewood', etc. A comparison of these words with the cognates in languages of other families of the Tupí stock show, however, that both $d$ (or $n$-) and $t$ - may have originally been prefixes: in Tupínambá and in Old Guaraní, for instance, the stems -atá 'fire', - $\tilde{a} j$ 'tooth', and -uwý 'blood' are abstracted not only form the oppositive pairs X $r$-atá 'X's fire' / s-atá 'his fire', X $r-\tilde{a} j-a$ 'X's tooth' / $s-\tilde{a} j-a$ 'his tooth', but also from compounds and derivatives where the stems occur independently of any relational prefixes, as in Tupínambá ma?é-atá 'thing that has fire' (Anchieta 1595:9), merú-ãj-a 'toothed fly' (Rodrigues 1958b:36), Old Guaraní a-je-mo-uwý 'I bleed myself' (Ruiz de Montoya 1876:401/395).

\subsection{Mawé}

Another member of the Tupí stock is Mawé, which constitutes a linguistic family per se. In Mawé (Sateré dialect), spoken between the mouths of the Madeira and Tapajós rivers in the State of Amazonas, Brazil, the same contiguity/non-contiguity pattern is found:

$\begin{array}{lccc} & \text { Class A }_{1} & \text { Class }_{2} & \text { Class B } \\ \text { Contiguity } & \emptyset_{-} & s- & \emptyset- \\ \text { Non-contiguity } & h- & h- & i-\end{array}$

Class A stems begin with a vowel and class B stems, with a consonant. Examples are taken from Graham and Harrison (1984):
(16a) kahi ø-eha
parrot REL-eye
'the parrot's eye'
(16b) toisuk h-eha
he.pierces REL-eye
'he pierces its eye' 
(17a) kahi $ø-p \dot{i}$

parrot REL-foot

'the parrot's foot'

(17b) to?akasa i-pi

he.sees REL-foot

'he sees its foot'

(18a) h-aat

REL-seize

'it was seized'

(18b) kahi s-aat

parrot REL-seize

'the parrot was seized'

(19a) kahi ø-kuap

parrot REL-know

'the parrot is known'

(19b) i-kuap

REL -know parrot

'it is known'

The agreement just seen among languages of four members of the Tupí linguistic stock points to the existence of the same syntactic and morphological pattern in Proto-Tupí, even though an accurate phonological reconstruction of Class A prefixes has not yet been achieved. The most likely reconstruction of the whole pattern on the basis of the data presented here appears to be the following:

$\begin{array}{lll} & \text { Class A } & \text { Class } \\ & \text { V-initial stems } & \text { C-i } \\ \text { Contiguity } & (?) & *^{\circ-} \\ \text { Non-contiguity } & *_{t-\text { or }}^{*} t s- & *_{i-}\end{array}$

This same morphosyntactic pattern is found also in some languages that do not belong to the Tupí stock, namely languages of the Karíb family and of the Macro-Jê linguistic stock. The Karíb family has been shown to be 
probably more akin - in so far as lexicon and phonological correspondences are concerned - to the Tupí stock (Rodrigues 1985). For one of the languages of the Macro-Jê stock, Kaingáng, which is immediately affiliated with the Jê family, lexical and phonological evidence of a possible genetic relationship with Tupí was presented by Rodrigues (1978).

\section{Karíb}

\subsection{Hixkaryána}

One of the best known languages of the Karíb family is Hixkaryána, spoken on the Nhamundá, a northern affluent of the Amazon river, in the northwest of the Brazilian state Pará. Derbyshire (1985:199-200) analyzes the person making prefixes of this language as including two non-reflexive $3^{\text {rd }}$ person markers: "III with a preceding NP: $j-, \varnothing_{-}$" and "III without a preceding NP: $y, u$ - (stem-initial change $o \rightarrow e$ ), $\varnothing^{-}$-". This turns out to be another way of describing the distinction between contiguous and non-contiguous determiner. The allomorphs $j$ - and $\varnothing$ - of "III with a preceding NP" occur with stems beginning with vowels and with consonants, respectively; the allomorph $y$ ( $u$ - results from $y$-being assimilated to an $u$ in the first syllable of the stem, cf. Derbyshire 1985:182-3) of "III without a preceding NP" occurs with stems beginning with a consonant, and allomorph $\varnothing^{-}$, with stems beginning with the vowel. Leaving out $o \rightarrow e$, a morphophonemic phenomenon restricted to stems beginning with the vowel $o$, we can display Hixkaryána prefixes in the same pattern as found in the Tupían languages:

$\begin{array}{lcc} & \text { Class A } & \text { Class B } \\ \text { Contiguity } & j- & \varnothing- \\ \text { Non-contiguity } & \varnothing- & i-\end{array}$

Examples (data from Derbyshire 1985):
(20a) waraka j-amori
waraka REL-hand
'waraka's hand.'
(20b) ø-amori
REL-hand
'his hand' 
(21a) í-kanawari

REL-canoe

'his canoe'

(21b) waraka ø-kanawari

waraka REL-canoe

'waraka's canoe'

\subsection{Taulipáng}

Taulipáng, spoken on the border of the Brazilian state Roraima with Guiana, reproduces the same pattern as Hixkaryána:

$\begin{array}{lc}\text { Class A } & \text { Class B } \\ \text { V-initial stems } & \text { C-initial stems } \\ j- & \emptyset_{-} \\ i t- & i-\end{array}$

Examples (data from Koch-Grünberg 1928):

(22a) alaid j-eli

piranha REL-tooth

'piranha's tooth'

(22b) it-e

REL-tooth

'its tooth'

(23a) Makunaima ø-mini

Makunaima REL-blood

'Makunaima's blood'

(23b) i-mini

REL-blood

'his blood' 


\subsection{Arára}

Whereas Hixkaryána and Taulipáng are representatives of two distinct subgroups of North Amazonian Karíb, Arára is a South Amazonian Karíb language spoken on the Iriri river, between the lower Xingu and the lower Tapajós, in the Brazilian state Pará. Arára has a contiguity/non-contiguity pattern resembling that of Hixkaryána, except for the fact that the contiguity marker in class A stems has two allomorphs, $j$ - and $\varnothing$-, the former occurring only when the contiguous determiner ends in a consonant; otherwise the allomorph ø- occurs. Examples from Souza (1993):

(24.a) Maude o-lati

Maude REL-mouth

'Maude's mouth'

(24.a) Maude o-lati

Maude REL-mouth

'Maude's mouth'

(24.b) i-lati

REL-mouth

'his mouth'

(25.a) Maude ø-aborimuru

Maude REL-mouth

'Maude's forearm'

(25b) Piput j-aborimuru

Piput REL-forearm

'Piput's forearm'

(25c) Ø-aborimuru

REL-forearm

'his forearm'

The contiguous/non-contiguous pattern in Arára looks therefore as follows: 
Class A Class B

Contiguity

$\mathscr{\varnothing - ,} j-$

$\varnothing-$

Non-contiguity

$\theta_{-}$

$i-$

\section{Macro-Jê}

\subsection{Jê family}

\subsubsection{Timbíra}

Let us turn now to some languages of the Jê linguistic family. A good representative of this family is Timbíra, a dialect cluster spoken by a part of the Northern Jê peoples. The Canela dialect of Timbíra has been recently described by Popjes \& Popjes (1986). These authors state: "the following morphological rule operates throughout a major part of the language: $j$ and $x$ occurring phrase medial become $h$ phrase initial." (1986:193; in their transcription $x$ stands for $/ t s /$ ). They do not see $j$-, $t s$ - and $h$ - as prefixes and for this reason they do not use them for distinguishing verb (and noun) classes on the basis of alternating prefixes; rather, they put words with the alternations $j$ $\sim h$ - and $t s$ - $\sim h$ - in the same class where they put words with prefix zero, since they consider $j$-, $t s$-, and $h$ - as parts of the stems where these appear (1986:1947). Thus, besides zero, Popjes \& Popjes identify $i$-, $i^{\text {? }}$-, im-/in-, and $k u$ - (written $\mathrm{cu}-)$ as $3^{\text {rd }}$ person prefixes serving as a basis for classifying stems in up to five morphological classes. However, since the non-zero prefixes in this set occur only with stems beginning with a consonant, it is appropriate to subsume these stems in one larger class comprising several subclasses, including one with a true zero prefix, and to set up another class with the stems that display the alternations $j-\sim h$ - and $t s-\sim h$ - by considering these as beginning with a vowel and receiving $j$ - and $h$ - or $t s-\sim h$ - as prefixes. According to this reanalysis, $h$ in the vocalic class corresponds to $i$-, etc., in the consonantal class, and occurs only when a nominal determiner contiguously precedes the verb or noun, a situation in which stems beginning with a consonant have a zero marker. This reanalysis reveals for Timbíra the very same morphosyntactic pattern found in the Tupían and Karíban languages: 


$\begin{array}{ccc}\text { Class } \mathrm{A}_{1} & {\text { Class } \mathrm{A}_{2}} & \text { Class B } \\ \text { V-initial stems } & \text { V-initial stems } & \text { C-initial stems } \\ j- & t s- & \emptyset- \\ h- & h- & i-, k u-, \varnothing^{-}\end{array}$

Examples (from Popjes \& Popjes 1986):
(26a) ku-tè
атро̀
j-apror
he-PAST something REL-buy
'he bought something'

(26b) ku-tè h-apror

he-PAST REL-buy

'he bought it'

(27a) pjen ts-om

sand REL-grain

'grains of sand'

(27b) h-om

REL-grain

'kernels'

(28a) Kapi ø-tò

Capi REL-eye

'Capi's eye'

(28b) i-ntò

REL-eye

'his eye'

(29a) Kapi Ø-mã

Kapi REL-to

'to Capi'

(29b) ku-mã

REL-to

'to him' 


\subsubsection{Panará}

Panara is the language of the people known under the name Kren-akarore, living west of the Upper Xingu river, but descending from the Southern Kayapó, which from the beginning of the $18^{\text {th }}$ to the beginning of the $19^{\text {th }}$ century have been living on the upper Paraná river basin, mainly on its tributaries Paraíba and Grande (Rodrigues and Dourado 1993). Although differing from Timbíra in many important respects, Panará has the same morphosyntactic pattern for contiguity/non-contiguity as Timbíra, but has eliminated the marker of non-contiguity from a part of the roots in class B, thereby creating a subclass $\mathrm{B}_{2}$, where both markers are $\varnothing$-:

Contiguity

Non-contiguity

\begin{tabular}{|c|c|c|}
\hline Class A & Class $B_{1}$ & \\
\hline$j-$ & ${ }^{\circ-}$ & \\
\hline$S-$ & $\tilde{l}^{-}$ & $\theta-$ \\
\hline
\end{tabular}

Examples (data from Luciana G. Dourado, personal communication; see also Dourado 1990 and 1993):

(30a) sòti j-akoa

animal REL-mouth

'the mouth of the animal'

(30b) s-õtò s-akoa amã

REL-tongue REL-mouth in

'the tongue is in the mouth'

(31a) mara o-tè

he REL-leg

'his leg'

(31b) mara hẽ rõkre i-tè

he AGENT scratch REL-leg

'he scratched his leg' 
(32a) winsi Ø-ĩntò

mother REL-leg

'the mother's eye'

(32b) Ø-ĩntò kĩn

REL-eye good

'the eye is good'

(33a) mara ø-sua

he REL-tooth

'his tooth'

(32b) по̃piõ ø-sua

three REL-tooth

'three teeth'

\subsubsection{Kaingáng}

Kaingáng is one of the languages of the Southern Jê. Together with Xokléng, the other surviving Southern Jê language, it is the lexically most divergent member of the Jê family. In her description of the Paraná dialect of Kaingáng, Wiesemann (1972:89-90) states that some roots have an allomorph beginning

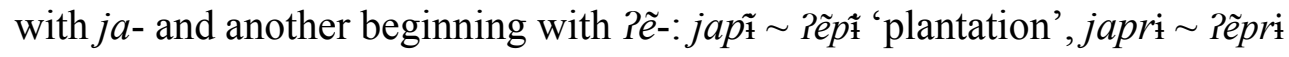
'path'. The first allomorph occurs when the root is the governing member ("Nukleus", "näher bestimmt") of a possessive nominal phrase; the other allomorph appears elsewhere:
(34a) ti jap $\ddot{\mathbf{I}} \quad$ 'his plantation'
(34b) Rẽp̃̃ tà 'in the plantation'
(35a) ti japri 'his path'
(35b) Rẽpri mĩ 'along the path'

In the examples above $t i$ 'he, his' is a pronominal word and not a prefix. Kaingáng has no personal prefixes but only personal pronouns, which behave syntactically like any nominal phrase. Thus, instead of $t i$ japri we can have kanhgâg japri 'the Indian's path'. 
In the light of the facts of Timbíra and Panará, the allomorph japri may be analyzed as $j$-apri and the allomorph Rẽpri as 2 -ẽpri (or as $\varnothing$-ẽpri if we consider that in Kaingáng, although Wiesemann treats $?$ as a phoneme, this sound may be treated as an automatic phonetic onglide before words that phonologically begin with a vowel (Cavalcante 1988). In the Paraná dialect of Kaingáng there are at least 16 roots that behave like the examples given above (Wiesemann 1971). These could be remnants from a time when the same morphosyntactic pattern of Timbíra and Panará prevailed also in preKaingáng:

Contiguity

Class A

Class B

Non-contiguity

$j-\quad \quad \theta_{-}$

P- or $\varnothing-\quad \theta-$

\subsection{Ofayé}

Ofayé, spoken west of the upper Paraná, between the Ivinheima and the Verde rivers in Mato Grosso do Sul, was considered a linguistic isolate by Nimuendajú (1980[1944]). Gudschinsky, who published a descriptive essay on Ofayé (Gudschinsky 1974), presented some phonological and lexical correspondences between it and Proto-Jê and suggested that it should be considered not as a member of the Jê family, but as directly coordinate with Proto-Jê (Gudschinsky 1971). It is therefore an isolate at the family level and a probable branch of the Macro-Jê linguistic stock (cf. Rodrigues 1986). A reanalysis of Gudschinsky's descriptive data reveal that Ofayé has a class of words, say A, beginning with a vowel, which receives a prefix $\int$ - when immediately preceded by an NP determiner that is either a possessor or a subject of a descriptive verb, and receives a prefix $h$ - when the determiner does not immediately precede:

(36a) pikitièn J-èn fit ' the heart of the caiman'(Gudschinsky 1974:210)
(36b) h-èn $\int \mathrm{f} h$
'its heart
(Gudschinsky 1974:194)
(37a) pièn $\int-\grave{e} f \mathrm{i} h$ 'the water is cold'
(Gudschinsky 1974:226)
(37b) $h$-è $f \mathfrak{i} h$
'it is cold'
(Gudschinsky 1974:226)

This class of words contrasts with another, say B, whose members begin with a consonant and, in the same conditions as for A, receive the prefixes $\varnothing$-and i-, respectively: 


$\begin{array}{llll}\text { (38a) pèrkrèn } & \varnothing-k i t e ? & \text { 'the egg of the bird' } & \text { (Gudschinsky 1974:210) } \\ \text { (38b) i-kite? } & & \text { 'its egg' } & \text { (Gudschinsky 1974:239) } \\ \text { (39a) hìhpar } & \varnothing \text {-ha?. } & \text { 'manioc peel' } & \text { (Gudschinsky 1974:210) } \\ \text { (39b) i- } h a ? & & \text { 'its peel' } & \text { (Gudschinsky 1974:240) }\end{array}$

Both class A and class B comprise only inalienably possessed nouns and descriptive verbs. As it may easily be seen, classes A and B of Ofayé reproduce the same morphosyntactic pattern of the Tupí, Karíb, and Jê languages:

$\begin{array}{lcc} & \text { Class A } & \text { Class B } \\ \text { Contiguity } & \int- & \emptyset- \\ \text { Non-contiguity } & h- & \text { i- }\end{array}$

\subsection{Karajá}

Karajá is a small family, or simply a dialect cluster (including Southerm Karajá, Northern Karajá, Javaé, and Xambioá), whose speakers live in Central Brazil, on the Bananal Island and extending a little northwards and a little southwards of it along the Araguaya river. Karajá is another probable member of the Macro-Jê stock and Davis (1968) has presented good phonological and lexical evidence of its relationship with Jê. In a first essay on the grammar of Karajá, D. Fortune (1964) distinguished four classes of nouns according to the pronominal prefixes with which they occur. A closer examination of these classes has revealed that some of the variation ascribed by Fortune to the pronominal prefixes can be interpreted as due to the presence of relational prefixes of the kind found in Tupí, Karíb, and Jê, as seen above (Ribeiro 1996). Reordering Ribeiro's data, the same binary distinction into classes A and B emerges just as in the languages so far presented here:

$\begin{array}{lccc} & \text { Class A1 } & \text { Class A2 } & \text { Class B } \\ \text { Contiguity } & l- & d- & \emptyset- \\ \text { Non-contiguity } & h- & \mathrm{d}(?) & i-\end{array}$

Examples from Ribeiro (1996 and personal communication):

(40) habu l-awò

man REL-canoe

'the canoe of the man' 
(41) wa l-awò

1 REL-canoe

'my canoe'

(42) h-awò

REL-canoe

'the canoe'

(43) kuladu d-èbò

child REL-hand

'the hand of the child'

(44) wa d-èbò

1 REL-hand

'my hand'

(45) đ-èbò

REL-hand

'his (own) hand'

(46) Ø-èbò

REL-hand

'your hand'

(47) kuladu ø-asikò

child REL-arm

'the child's hand'

(48) wa ø-asikò

1 REL-arm

'my arm'

(49) i-asikò

REL-arm

'his arm' 
'I will shoot (with) the arrow'

(51)

$$
\begin{aligned}
& \text { i-di } \quad \text { arehukre } \\
& \text { REL-with } \quad \text { I.will.shoot } \\
& \text { 'I will shoot (with) it' }
\end{aligned}
$$

Seen from a diachronic point of view, Karajá appears to have undergone some changes in the use of the relational prefixes, particularly in stems of class A2. On the one hand, an original prefix for first person has probably been replaced by a personal pronoun $w a$, which behaved like a noun, asking for the contiguity prefix in the noun determined by it, as in (41) and (44). On the other hand, the traditional prefix for the second person $a$ - acquired analogically the same status of $w a$, i. e., it became a personal pronoun, as in $a$ l-awo 'your canoe', except in the case of a restricted set of stems referring to inalienable possession, such as ø-èbò 'hand' and ø-òròd $\grave{o}$ 'tongue', in which it was maintained as a prefix, but (subsequently) assimilated to the following vowel and apparently disappeared by contraction: $* a-e b \grave{o}>* e-e b \grave{o}>e b \grave{o}$ 'your hand', *a-òròd $\grave{o}>* \grave{o}$-òròd $\grave{o}>*$ òròd $\grave{o}$ 'your tongue'. Moreover, the non-contiguity prefix $i$-, as well as the coreferential prefix $\vee a$-, came also to be handled as pronominal words and, in analogy with $w a$, asked for the contiguity prefix in the A class nouns: $i$ l-awò 'his canoe', dal-awò 'his own canoe'. (examples from Fortune 1964).

\subsection{Karirí}

The Karirí linguistic family comprises a few languages in northeastern Brazil, all of them no more spoken. Although Swadesh supposed it belonged to his Macro-Caribe phylum and Greenberg (1987) presented it as a component of his Equatorial group (the only proposals acknowledged by Kaufman 1990:48), it is more likely a further branch of the Macro-Jê stock (Rodrigues 1986, 1999). The best known language of the family is Kipeá, that was described in the $17^{\text {th }}$ century by Mamiani. This author distinguished in it five "declensions" of the nouns, verbs, and prepositions, according to the forms taken by the pronouns with which they combine (Mamiani 1877[1699]:8-12). 
The following are the paradigms of the first four "declensions" illustrated here with nouns (Mamiani 1877[1699]:12-21):

$\begin{array}{lllll} & \begin{array}{l}1^{\text {st }} \\ \text { padzu } \\ \text { 'father' }\end{array} & \begin{array}{l}2^{\text {nd }} \\ \text { ambe } \\ \text { 'payment' }\end{array} & \begin{array}{l}3^{\text {rd }} \\ \text { ebaja } \\ \text { 'finger nail' }\end{array} & \begin{array}{l}4^{\text {th }} \\ \text { bate } \\ \text { 'dwelling' }\end{array} \\ 2^{\text {'my' }} & \text { hipadzur' } & \text { hiambe } & \text { hidzebaja } & \text { hibate } \\ 12 \text { 'our (INCL)' } & \text { epadzu } & \begin{array}{l}\text { ejambe } \\ \text { kambe }\end{array} & \text { edzebaja } & \text { ebate } \\ 3 \text { 'his/her/their' } & \text { ipadzu } & \text { sambe } & \text { sebaja } & \text { kubate } \\ \end{array}$

There is a fifth form in each paradigm, not included in these by Mamiani, but described by him elsewhere (Mamiani 1877[1699]:8, 62-63). This is for the coreferential $3^{\text {rd }}$ person $(3 \mathrm{c})$ and shows up as follows:

3c dipadzu dambe debaja dibate

What follows is a reanalysis of the Kipea paradigms based on the hypothesis that the markers for ' 1 ' and ' 2 ' are pronominal words, whereas the markers for $12,3 \mathrm{c}$, and 3 are true prefixes. This accounts easily for the $1^{\text {st }}$ and $3^{\text {rd }}$ "declensions", which comprise stems beginning with a consonant and a vowel, respectively:

$\begin{array}{lll} & 1^{\text {st }} & 3^{\text {rd }} \\ 1 & \text { hi padzu } & \text { hi dzebaja } \\ 2 & \text { e padzu } & \text { e dzebaja } \\ 12 & \text { kupadzu } & \text { kebaja } \\ 3 \mathrm{c} & \text { dipadzu } & \text { debaja } \\ 3 & \text { ipadzu } & \text { sebaja }\end{array}$

The prefixes $k u$ - ' 12 ' and $d i$ - ' $3 c$ ' lose their vowels before stems beginning with a vowel. Stems of the $3^{\text {rd }}$ "declension" have $s$ - instead of $i$ - of the $1^{\text {st }}$ "declension" as a marker of ' 3 ' and receive a prefix $d z$ - when preceded by the pronominal words $h i$ 'I' and $e$ 'you'. The stems of the $2^{\text {nd }}$ "declension" also begin with a vowel, but have $j$ - as a prefix instead of $d z$ - of the $3^{\text {rd "declension" }}$ after $h i$ and $e$; this $j$-drops (or was not perceived by Mamiani) after the vowel 
of the pronominal word $h i$ : ${ }^{*} h i j$-ambe $\rightarrow$ hi ambe. Mamiani lists a few words beginning with a vowel in the $1^{\text {st }}$ "declension"; it is assumed here that these would begin with a glottal stop that was systematically left without notation by him, so that his anhá 'aunt', ebejá 'shin', etc., should be Rana, Rebeja, etc. Under this assumption all stems following the $1^{\text {st }}$ "declension" begin with a consonant. The $4^{\text {th }}$ "declension" is also a set of stems beginning with a consonant, but its marker for ' 3 ' is apparently the result of a conjunction of the allomorphs $s$ - and $i$-. Hypothesizing that the Kipeá markers for $1^{\text {st }}$ and $2^{\text {nd }}$ person are pronominal words and not prefixes, whereas the remaining person markers are prefixes, is not as arbitrary as it could at first sight appear. This would only reproduce a situation that is familiar in Tupí, Jê and Karíb languages. Most Tupí-Guaraní languages have prefixes only for 3 and $3 c$ and use pronominal words for the other persons, as in the following Tupínambá paradigm, where pronominal words behave like any NP:

$\begin{array}{lll}\mathrm{NP} & \text { pajé } r \text {-esá } & \text { 'the eyes of the shaman' } \\ 1 & \text { sjé } r \text {-esá } & \text { 'my eyes' } \\ 2 & \text { né } \text {-esá } & \text { 'your (SG) eyes' } \\ 13 & \text { oré } r \text {-esá } & \text { 'our (EXCL) eyes' } \\ 12 & \text { jané } \text {-esá } & \text { 'our (INCL-FOCAL 3) eyes' } \\ 123 & \text { asé } \text {-esá } & \text { 'our (INCL+FOCAL 3) eyes' } \\ 23 & \text { pé } \text {-esá } & \text { 'your ( } \mathrm{PL} \text { ) eyes' } \\ 3 \mathrm{c} & \text { o-esá } & \text { 'his/her/their own eyes' } \\ 3 & \text { s-esá } & \text { 'his/her/their eyes' }\end{array}$

Timbíra (Jê) presents an analogous situation, where 1 and 2 are pronominal words, but 12 and 3 are prefixes (I reanalyze Popjes \& Popjes' data, assuming stems that begin with a $\mathrm{NC}$ cluster and drop $\mathrm{N}$ at word beginning, instead of assuming sets of allomorphs for the prefixes, namely pa- pam- $\sim$ pan- and $i$ - $\sim i m-\sim i n-$, as those authors do). The Timbira paradigm looks as follows:

$\begin{array}{llll}\text { NP } & \text { Kapi } & \text { Ø-to } & \text { 'Capi's eyes' } \\ 1 & \mathrm{i} & \varnothing-t \mathrm{~s} & \text { 'my eyes' } \\ 2 & \mathrm{a} & \varnothing-t \mathrm{~s} & \text { 'your eyes' } \\ 12 & & \text { pa-nto } & \text { 'our (INCL) eyes' } \\ 3 & & i \text {-nto } & \text { 'his/her/their eyes' }\end{array}$


In Hixkaryána, as in most Karíb languages, only for ' 13 ' a pronominal word is used (the marker $r o-\sim r$ - for 1 is an innovation of Hixkaryána and (as noted by S. Gildea, personal communication) probably originated in a proclitic use of the pronoun uro 'I', but behaves now as a true prefix:

$\begin{array}{lll}\text { NP } & \text { Warakaj-owani } & \text { 'Waraka's chest' } \\ 13 & \text { amnaj-owani } & \text { 'our (EXCL) chests' } \\ 1 & \text { r-owani } & \text { 'my chest' } \\ 2 & \text { oj-owani } & \text { 'your chest' } \\ 12 & k \text {-owani } & \text { 'our (INCL) chests' } \\ 3 \mathrm{C} & \text { t-owani } & \text { 'his/her/their own chest(s)' } \\ 3 & \text { ewani }(<* i \text {-owani }) & \text { 'his/her/their chest(s)' }\end{array}$

In Kipeá, however, the pronominal words $h i$ ' 1 ' and $e$ ' 2 ' are the only NPs that immediately precede nouns, verbs, and adpositions, so that they are probably relicts of a previous state of the language, when this was GN, SOV, and postpositional like most Jê and Tupí languages. The syntax of documented Kipeá is predominantly NG, VS, and prepositional, as in the following examples: s-era karai (his-house white.man) 'the white man's house', but hi (j-)era (1 (REL-)house) 'my house', e j-era (2 REL-house) 'your house'; si-pa-kri no karai (3-be.killed-PERF by white.man) 'he/it was killed by the white man', but si-pa-kri e na (3-be.killed-PERF you by) 'he/it was killed by you'.

Seen from the point of view of the marking of contiguity and noncontiguity of a determiner, Kipeá reveals the same pattern as found in the languages of the Tupí, Karíb, and Jê groups, as well as in Ofayé:

$\begin{array}{llll} & \text { Class A }_{1} & \text { Class A }_{2} & \text { Class B } \\ & \text { V-initial stems } & \text { V-initial stems } & \text { C-initial stems } \\ \text { Contiguity } & d z- & j- & \varnothing- \\ \text { Non-contiguity } & s- & s- & i-,(s i-)\end{array}$

\subsection{Boróro}

The Boróro linguistic family in the upper basin of the Paraguay river in southwestern Mato Grosso and eastern Bolivian Chaco is a further possible branch of the Macro-Jê stock (Davis 1968, Rodrigues 1986, 1999, Greenberg 
1987). Eastern Boróro, which is the best known language of the family, makes no contrast between contiguously and non-contiguously determined nouns:

Kuruiedi $\quad$ u-mana (Crowell 1979:215)

Kuruiedy 3sG-older.brother

'Kuruiedy's older brother'

(52b) u-mana

3sG-older.brother

'his older brother'

The prefix $u$ - (and its allomorphs) has been recognized as a $3^{\text {rd }}$ on a par with the personal prefixes for other persons, namely $i$ - ' 1 ', $a$ - ' 2 ', $p a-$ ' 12 ', $\check{c} e$ ' 13 ', $t a$ - '23', $e$ - '33', $t \dot{t}$ - '3C', $p u$ - '3R' (3R for reciprocal 3 $3^{\text {rd }}$ person) (Crowell 1979:206). Thus, $u$ - is not a relational prefix as those found in the Tupí, Karíb, and Jê languages and there is in Boróro no marker of contiguity or noncontiguity of the determiner. But Boróro presents some features that make its inflexion of person more comparable to that of the Jê languages. First, its person markers for ' 1 ', ' 2 ', and '12' are homophonous with those of Timbíra: ' 1 ' $i-$, ' 2 ' $a-$, ' 12 ' $p a-$. Second, the allomorphy of Boróro $u$ - ' $3 \mathrm{sG}$ ' includes $i-, \breve{J}$-, and $\varnothing^{-}$, what is phonologically more comparable to the allomorphs $i$ - and $\varnothing$-of the non-contiguity marker of Timbíra. Third, Boróro is described as inserting a consonant between the person markers and several classes of stems beginning with a vowel, this consonant being a velar stop throughout the person paradigm (except for ' $3 \mathrm{sG}^{\mathrm{s}}$ ' and ' $3 \mathrm{c}$ ') when the initial vowel of the stem is front and an alveolar one (in general oral, but in some words nasal) when the initial vowel of the stem is back (Crowell 1977:164-66, 167, 1979:207-209); as it was recently pointed out (Rodrigues 1993), the inserted consonants may have originated historically from a $* j$ - comparable to the Timbíra contiguity marker $j$-, as seen in such parallel forms as:

$\begin{array}{lll}\text { Boróro } & \text { Timbíra } & \\ i-n-o & i j-\tilde{o} & \text { 'my belongings' } \\ a-k-o & a j-\tilde{o} & \text { 'your (SG) belongings' } \\ p a-g-o & p a j-\tilde{o} & \text { 'our (INCL) belongings' } \\ \varnothing-o & h-\tilde{o} & \text { 'his/her belongings' }\end{array}$


This parallelism is an indication that in a previous state of Boróro the inserted consonant may have been a marker for contiguity as in Timbíra. On the other hand, the prefix $\varnothing$ - (and its allomorphs) for ' 3 ' may have been a marker of non-contiguity as the relational prefix $h$ - of Timbíra, having developed into a ' 3 ' marker in association with some syntactic changes. The reflex of the original morphosyntactic pattern in Boróro could be represented as follows (for the phonological changes assumed in class A, see Rodrigues 1993):

$\begin{array}{lll} & \text { Class A } & \text { Class B } \\ \text { Contiguity } & k-/ g-, t-/ d / n-\left(<*^{*}\right) & \emptyset_{-} \\ \text {Non-contiguity } & \emptyset_{-} & u-, i-, j-\varnothing-\end{array}$

As in Kipeá (Karirí), the situation of contiguity is restricted to the presence of the pronominal words. These markers, which are called bound pronouns by Crowell (1979:206), have really the status of pronominal words, since they may occur in morphological independence from the verb as bases for aspectual markers as well as for negation:

$$
\begin{array}{lll}
\text { a-re } & \text { karo } & \text { bi (Crowell 1979:88) } \\
\text { 2sG-neutral fish put } \\
\text { 'you put the fish down', }
\end{array}
$$

$$
\begin{array}{lrl}
\text { a-ka-re } & \text { karo } & \text { bi (Crowell 1979:88) } \\
\text { 2SG-NEG-NEUTRAL } & \text { fish } & \text { put } \\
\text { 'you didn't put the fish down' } &
\end{array}
$$

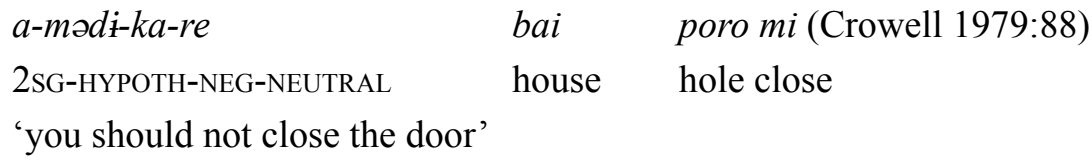

\section{Conclusion}

The data presented above show clearly that one and the same morphosyntactic pattern for the expression of the syntactic relationship of a term with its determiner is shared by languages of the Karíb family and of the Tupí and 
Macro-Jê stocks. They show, moreover, that there is even a good deal of phonological consistency in the representation of the morphemes that fulfill the pattern in each language, so that the likelihood of cognacy is very strong. Although there is not yet enough lexical comparative data for establishing regular phonological correspondences among Macro-Jê on the one hand and Tupí and Karib on the other (for the latter two with one another a first list of regular correspondences was contributed in Rodrigues 1985) as well as among the branches of Macro-Jê (for Jê-Karajá and Jê-Maxakalí see Davis 1968, for Jê-Ofayé see Gudschinsky 1971), the most probable ancestor of the morphosyntactic pattern examined here could not be too different from the following (where $D$ stands for a probable coronal stop:

$\begin{array}{lll} & \text { Class A } & \text { Class B } \\ & \text { V-initial stems } & \text { C-initial stems } \\ \text { Contiguity } & * D- & *{ }^{-} \\ \text {Non-contiguity } & * t s- & *_{i-}\end{array}$

\section{References}

Anchieta, Joseph de. 1595. Arte de grammatica da lingua mais usada na costa do Brasil. Coimbra.

Caspar, F.; A. D. Rodrigues. 1957. Die Tuparí Sprache. [Unpublished manuscript.]

Cavalcante, M. P. 1987. Fonologia e morfologia da Língua Kaingáng: o dialeto de São Paulo comparado com o do Paraná. Unpublished Ph. D. dissertation, Universidade Estadual de Campinas.

Crofts, Marjorie. 1973. Gramática Mundurukú. Série Linguística 2. Brasília: Summer Institute of Linguistics.

Crowell, Thomas. 1977. The phonology of Boróro verb, posposition and noun paradigms. Arquivos de Anatomia e Antropologia 2. Rio de Janeiro: Instituto de Antropologia. pp. 157-178.

Crowell, Thomas. 1979. A Grammar of Bororo. Unpublished Ph. D. dissertation, Cornell University.

Davis, I. 1968. Some Macro-Jê relationships. International Journal of American Linguistics 34:42-47.

Derbyshire, D. C. 1985. Hixkaryana and Linguistic Typology. Dallas: Summer Institute of Linguistics and University of Texas at Arlington. 
Dourado, L. G. 1990. Estudo preliminar da fonêmica em Panará. Unpublished M. A. thesis, Univesidade de Brasília.

Dourado, L. G. 1993. Tendências morfofonêmicas em Panará: uma proposta de análise. Boletim do Museu Paraense Emílio Goeldi, Série Antropologia 9.2:199-208.

Figueira, Luis. 1687. Arte de Grammatica da Lingua Basílica. Lisboa.

Fortune, David L. 1973. Gramática Karajá: um estudo preliminar em forma transformacional. Série Linguística 1:101-161. Brasília: Summer Institute of Linguistics.

Graham, A. and S., and C. H. Harrison. 1984. Prefixos pessoais e numerais da língua Sateré-Mawé. In: R. A. Dooley (ed.), Estudos sobre Línguas Tupí do Brasil. Brasília: Summer Institute of Linguistics. Pp. 175-205.

Greenberg, J. H. 1987. Language in the Americas. Standford: Standford University Press.

Gudschinsky, S. C. 1971. Ofaié-Xavante, a Jê language. Summer Insitute of Linguistics, Estudos sobre Linguas e Culturas Indígenas. Brasília. Pp. 1-16.

Gudschinsky, S. C. 1974. Fragmentos de Ofaié: a descrição de uma língua extinta. Série Linguística 3:177-249. Brasília: Summer Institute of Linguistics.

Kaufman, T. 1990. Language History in South America: What We Know and How to Know More. In: D. L. Payne (ed.), Amazonian Linguistics: Studies in Lowland South American Languages. Austin: University of Texas Press.

Koch-Grünberg, T. 1928. Vom Roraima zum Orinoco: Ergebnisse einer Reise in Nordbrasilien und Venezuela in den Jahren 1911-1913, 4: Sprachen. Stuttgart: Verlag Strecker und Schröder.

Mamiani, L. V. 1877 [1699]. Arte Grammatica da Lingua Brasilica da Naçam Kiriri. Rio de Janeiro: Biblioteca nacional.

Nimuendajú, C. 1980 [1944]. Mapa Etno-histórico do Brasil e Regiões Adjacentes. Rio de Janeiro: Fundação Instituto Brasileiro de Geografia e Estatística and Fundação Nacional Pró-Memória.

Popjes, J., and J. Popjes. 1986. Canela-Krahô. In: D. C. Derbyshire and G. K. Pullum, Handbook of Amazonian Languages, 1:128-199. Berlin: Mouton de Gruyter.

Ribeiro, E. R. 1995. Classes verbais em Karajá. Anais do IX Encontro Nacional da ANPOLL, Linguística, vol 2:1025-1038. João Pessoa: ANPOLL

Rodrigues, Aryon D. 1958a. Klassifikation des Tupí-Sprachstammes. In: Jens Yde (org.), Proceedings of the 32nd International Congress of Americanists, pp. 679-684. Copenhague: Munskgaard. 
Rodrigues, A. D. 1958b. Contribuição para a Etimologia dos Brasileirismos. Revista Portuguesa de Filologia 9:1-54.

Rodrigues, A. D. 1978. Kaingáng e Tupínambá: evidências de parentesco genético?. Unpublished paper read in the Meeting of the Associação Brasileira de Antropologia, Recife.

Rodrigues, A. D. 1980. Tupínambá e Mundurukú: evidências lexicais e fonológicas de parentesco genético. Estudos Linguísticos (Anais de Seminários do GEL) 3:194-209. Araraquara.

Rodrigues, A. D. 1985. Evidence for Tupí-Carib relationships. In: H. E. M. Klein and L. R. Stark (eds.), South American Indian Languages: Retrospect and Porspect. Austin: University of Texas Press. pp. 371-404.

Rodrigues, A. D. 1986. Línguas Brasileiras: para o Conhecimento das Línguas Indígenas. São Paulo: Edições Loyola.

Rodrigues, A. D. 1993. Uma hipótese sobre flexão de pessoa em Bororo. Anais da 45a. Reunião Anual da Sociedade Brasileira para o Progresso da Ciência, Recife. P. 509.

Rodrigues, A. D. 1999. Macro-Jê. In: R. M. W. Dixon and Alexandra Aikhenvald (eds.) The Amazonian Languages. Cambridge: Cambridge University Press, p. 165-206.

Rodrigues, A. D., e L. G. Dourado. 1993. Panará: identificação linguística dos Kren-Akarore com os Cayapó do Sul. Anais da 45a Reunião Anual da Sociedade Brasileira para o Progresso da Ciência, Recife. P. 505.

Ruiz de Montoya, A. 1876 [1639]. Tesoro de la Lengua Guaraní. New edition by V. de Porto Seguro. Viena/Paris.

Souza, S. D. C. de. 1993. Alguns Aspectos Morfológicos da Língua Arara (Karib). Unpublished M. A. thesis, Universidade de Brasília.

Wiesemann, U. 1971. Dicionário Kaingáng-Português, Português-Kaingáng. Brasília: Summer Institute of Linguistics.

Wiesemann, U. 1972. Die pohonologische und grammatische Struktur der Kaingáng-Sprache. The Hague: Mouton. 